\title{
Flipped Classroom at the Defence University
}

\author{
Juhary, Jowati and Amir, Ahmad Fahimi
}

Language Centre, National Defence University of Malaysia, Malaysia.

\begin{abstract}
Flipped classroom is not a new concept in education. Students are expected to be well-prepared before coming to face-to-face sessions since they have to read/watch/listen to the lectures through the learning management system (LMS) or an e-learning portal before coming to the classes. What traditionally was practised is that students were given lectures during faceto-face sessions. Now, the lectures are online, and only activities to enhance students' understanding will take place during face-to-face sessions. The concept is now being implemented successfully in some higher learning institutions in Malaysia, including Universiti Sains Malaysia, Penang; Universiti Malaysia Sabah, Sabah; and Universiti Kebangsaan Malaysia, Selangor. In fact, the emphasis is given by the Ministry of Higher Education, Malaysia for all higher learning institutions to incorporate the use of technology in teaching and learning. Given this, the National Defence University of Malaysia (NDUM) must also be prepared to rise to this challenge. This research becomes the main study on the use of flipped classroom at the Defence University.
\end{abstract}

Keywords: Defence University; digital technologies; face-to-face sessions; flipped classroom. 


\section{Introduction}

Flipped classroom is not new in the education landscape. When an instructor asked the students to read page 4 of the textbook, for example, and the next class would be dedicated to discussing and debating what page 4 is all about, it is considered a flipped concept. This is because the definition of flipped classroom has not changed over time; the only thing that changes is the medium of 'flipping.' Today, flipped classroom suggests that the students are expected to read/watch/listen to the lectures through the learning management system (LMS) or an e-learning portal before coming to the classes. What traditionally was practised is that students were given lectures during face-to-face sessions. Now, the lectures are online, and only activities to enhance students' understanding will take place during face-to-face sessions.

The drivers for using flipped classroom, which is part of the tools for e-learning, are threefold, including the National Higher Education Strategic Plan launched in 2007; the National e-Learning Policy launched in April 2011; and the Malaysia Education Blueprint (Higher Education) launched on 7th April 2015. All these highlight the importance of digital technologies in teaching and learning, which promotes more quality digital content and becomes an aggressive push towards making Malaysia a renowned higher education hub.

Given this, the National Defence University of Malaysia (NDUM) must also be prepared to rise to this challenge. The aim of this research is to examine the perceptions of students on the new concept of classroom learning. There are two main objectives including,

a. to determine the impacts of using flipped classroom on students

b. to identify the factors that may hinder or influence the use of flipped classroom by students

This research has two main research questions that will help to achieve the aim and objectives of the study. These research questions include,

a. What are the impacts of using flipped classroom on students?

b. What are the factors that may hinder or influence the use of flipped classroom by students?

The assumption of this research is that since flipped classroom is new at the NDUM, the researchers argue that it has huge potential to assist students in their learning process. This argument is based on the fact that students attending tertiary education today are digital natives. Therefore, it is assumed that students can rely on flipped classroom, especially to prepare them before coming to the face-to-face sessions. 


\section{Literature Review}

Research on flipped classroom demonstrates that the concept can empower students to take charge of their own learning. There is nothing new about flipped classroom (Lancester \& Read, 2013). In the past, students were expected to read a paragraph or a chapter before coming to class, and further discussion on the reading material would be facilitated by instructors in the classroom. The difference is just the delivery method or medium of 'flipping' and the time spent on delivering lectures during face-to-face sessions. With the demand to use e-learning in the Malaysian higher learning environment, flipped classroom through the LMS may encourage instructors and students alike to adopt technology in teaching and learning. Since flipped classroom could also foster learner autonomy, the technology can further assist in this effort.

Further, students who are in flipped classes progress faster because they understand the lessons better (Papadapoulos \& Roman, 2010). Perez and Dong (2012) also found that flipped classroom allows students to master design skills effectively. Other researchers suggest that flipped classroom also assists students' understanding of lessons in law and physics and thus, improves their retention of knowledge (Bates \& Galloway, 2012).

In Malaysia, some areas of flipped classroom have been studied by various scholars. Embi, Hussin and Panah (2014) found in their study that students at Universiti Kebangsaan Malaysia have an acceptable readiness to adopt the flipped classroom approach. Their study looked at technology access, online skills and relationships, motivation and the Internet discussion, amongst others. Further, another study by scholars in Universiti Malaysia Sabah found that there is a need to evaluate the contribution of flipped classroom in higher education, particularly when it is used as a complementary approach to the face-to-face sessions (Lee Kean Wah et al., 2014). In addition, at the International Medical University, it was found that the most successful faculty in implementing flipped classroom is the School of Pharmacy (Alasagof, Baloch \& Hashim, 2014). The other faculties, nonetheless, are also reported to be doing their best in offering unique ways to engage students through flipped classroom.

Recent researches on flipped classroom keep promoting the advantages of using this concept for classroom teaching and learning. Rivera (2016) in her postgraduate thesis found that students' classroom engagement and efficiency improve when they are involved in flipped classroom. Further, McCarthy (2016) argued that flipped classroom provides more meaningful interaction between students. This suggests that students become active participants during classroom learning.

Notwithstanding this increase popularity of flipped classroom, there are also concerns about this concept. Amongst the critical ones is the fact that flipped classroom, as an approach, can be poorly executed. Sam and Bergmann (2012) argued that some instructors would 
totally replace themselves with videos uploaded online. Further, the skills of presenting through videos can vary between one instructor to the other, and the different styles of presenting will have to serve various needs of the students. In addition to this, concerns are also heard on the access of the Internet (Schmidt \& Ralph, 2014); this suggests that whether students are having the same amount of access at home or wherever they choose to view the online materials before coming to class. Eventually, according to Vanneman and Baker (2017), flipped classroom does not result in a statistically significant increase in knowledge acquisition.

\section{Methodology}

The research adopts a quantitative approach to research by means of a survey. There were two critical processes; first, students were required to use the online materials (e-content materials) developed by the researchers and attend face-to-face sessions to further explore the online contents, and second, they had to answer the survey online.

\subsection{Sample Population}

Selected students from the foundation year students were involved in this research. There were about 560 students at the foundation level when the study took place. Questionnaires were distributed online using Google.doc and notification about the survey was included in emails as well as the university's LMS. A pilot study was also conducted to check for validity of the items in the survey.

\subsection{Research Instruments}

The items in the survey were adopted from various sources (see Camel, 2011; Bates \& Galloway, 2012). All questionnaire items will use 4-point likert scale with 1 (Strongly Disagree), 2 (Disagree), 3 (Agree) and 4 (Strongly Agree).

Data collected were analysed using the Statistical Package for Social Sciences (SPSS) Version 25. Descriptive analysis includes using the frequency, standard deviation and mean.

\section{Findings and Discussions}

The findings originate from the online survey completed by 112 Foundation Year students. The online survey consists of three sections. The discussion starts first with the review of the demographic data of the respondents, followed by the data from the second section which scrutinises the perceptions of the respondents on flipped classroom. An overall 
analysis of the assumption will use also data from the third section of the online survey, in which respondents shared their opinions about flipped classroom.

\subsection{Data from Section A of the Online Survey}

Based on the figures below, it can be summarised that the respondents were mostly male students (62.5 percent) and the rest were female students. This is undisputable since the Defence University is preparing for the future defenders of the nation and thus, there is a positive discrimination against the number of female cadets and officers in the Malaysian Armed Forces. This is due to the limitations of posting areas and positions in the three military services in Malaysia.

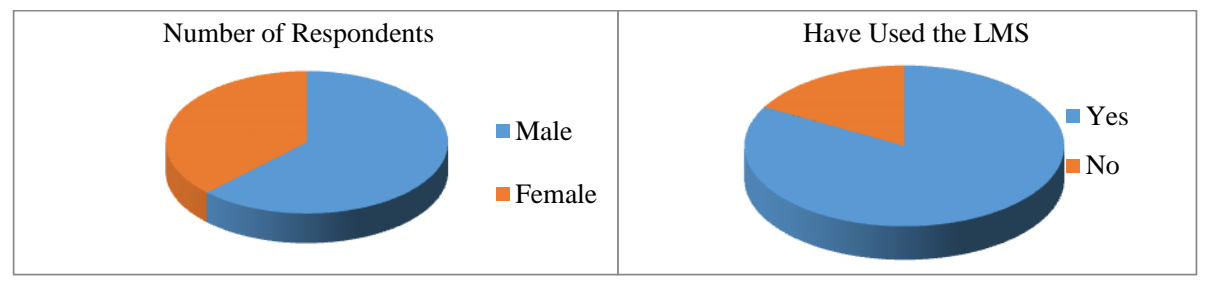

Fig 1. The Number of Respondents

Fig 2. The Experience of Students with the LMS

\subsection{Data from Section B of the Online Survey}

There are 30 questions in this section, and they are divided into several themes. All items seek respondents' opinions on flipped classroom. Table 1 below illustrates the findings from selected items of Section B. 
Table 1. Selected Items and the Responses (in percentage)

\begin{tabular}{|c|c|c|c|c|}
\hline & Items & $\begin{array}{l}\text { Agree/ } \\
\text { Strongly } \\
\text { Agree }\end{array}$ & $\begin{array}{l}\text { Standard } \\
\text { Deviation }\end{array}$ & Mean \\
\hline 1 & $\begin{array}{l}\text { The activities during Flipped Classroom session increase } \\
\text { my understanding of the course key concepts }\end{array}$ & 95.6 & .615 & 3.49 \\
\hline 2 & $\begin{array}{l}\text { The Flipped Classroom session inspires me to pursue } \\
\text { further learning for the course }\end{array}$ & 93.7 & .662 & 3.39 \\
\hline 3 & $\begin{array}{l}\text { My level of engagement for this course increases when it } \\
\text { is done through Flipped Classroom }\end{array}$ & 92.9 & .658 & 3.31 \\
\hline 4 & $\begin{array}{l}\text { Flipped Classroom allows me to participate more actively } \\
\text { in class when compared to traditional lectures }\end{array}$ & 86.6 & .776 & 3.33 \\
\hline 5 & $\begin{array}{l}\text { I think more lectures/classes should be conducted in the } \\
\text { Flipped Classroom mode }\end{array}$ & 89.3 & .755 & 3.29 \\
\hline 6 & $\begin{array}{l}\text { Flipped Classroom encourages me to read/find additional } \\
\text { materials outside of class }\end{array}$ & 79.5 & .788 & 3.21 \\
\hline 7 & $\begin{array}{l}\text { Flipped Classroom gives me more opportunity to discuss } \\
\text { with the lecturer }\end{array}$ & 92.9 & .679 & 3.41 \\
\hline 8 & I am more motivated to learn through Flipped Classroom & 86.6 & .697 & 3.23 \\
\hline 9 & Flipped Classroom has not enhanced my learning process & 29.5 & .977 & 2.10 \\
\hline 10 & $\begin{array}{l}\text { Flipped Classroom is more engaging than the traditional } \\
\text { classroom }\end{array}$ & 82.1 & .721 & 3.14 \\
\hline 11 & $\begin{array}{l}\text { Viewing the video lectures/online materials before } \\
\text { coming to class allows me to be ready with the class } \\
\text { activity }\end{array}$ & 97.3 & .551 & 3.55 \\
\hline 12 & $\begin{array}{l}\text { Flipped Classroom allows me to make use of the class } \\
\text { time more effectively with the lecturer }\end{array}$ & 95.5 & .659 & 3.38 \\
\hline 13 & $\begin{array}{l}\text { I would rather be involved in a class discussion than } \\
\text { sitting and listening to the lecture the whole time }\end{array}$ & 81.2 & .800 & 3.13 \\
\hline
\end{tabular}

Overall, the respondents were positive about the flipped classroom concept. This is not a surprise since these digital natives are so used to using technology in their daily life. Based on Table 1, more than 89 percent of the respondents chose to agree to these selected and critical items. The items I think more lectures/classes should be conducted in the Flipped Classroom mode and Viewing the video lectures/online materials before coming to class allows me to be ready with the class activity were positively chosen by 89.3 (standard deviation=.755; mean=3.29) and 97.3 (standard deviation=.551;mean=3.55) percent of the respondents respectively. Notwithstanding this, the respondents were also quite divided between their preferences of the flipped classroom concept. This is because 29.5 percent (standard deviation=.977; mean=2.10) of the respondents agreed that the concept has not enhanced their learning process. The researchers argue that this is expected since the concept is relatively new at the Defence University. This also signals that more exposure to 
the use of flipped classroom should be given to students, which ultimately suggests educators should adopt the concept too.

\subsection{Aligning the Assumption}

It is assumed that flipped classroom helps students to learn better and effectively. Based on the data, this assumption could be accepted but not without its consequences. These consequences fulfil the objectives of this paper; nonetheless, they are impactful to the bigger or major research on flipped classroom at the Defence University. These consequences are twofold as explained below.

First, based on the data gathered, the respondents admitted that the second phase of the pilot study was their first encounter with the flipped classroom concept. This is supported by the respondents' comments in Section C of the online survey, where they implied that they were not able to offer any comments because they have no ideas on the concept. This further highlights the importance of conducting further research into this area simply because there is not much information about flipped classroom at the Defence University. This poses another question: whether the educators are aware of the flipped classroom concept and whether they are prepared to apply this concept in their teaching practices. This could perhaps be addressed in another research project.

Second, the respondents were also critical about the e-content materials designed, developed and uploaded as part of the process to complete flipped classroom. Some respondents suggested that the questions/quiz at the end of each lesson should be replaced with educational games instead. The researchers justify this 'request' as a critical requirement of the $21^{\text {st }}$ century learners, who are mostly digital natives. Apart from that, the respondents also suggested that the e-content materials are developed through film making or creative animations. This, unquestionably, could retain the students' interest in learning. On top of that, the researchers would have to validate all materials and retest the flow and activities of the e-content materials.

\section{Conclusion}

There are three main research findings. Firstly, students today, considered digital natives, are very comfortable using technology for learning. Given this, educators must fine tune their teaching materials and activities to support students' needs. Secondly, using technology to support teaching and learning is more challenging than the conventional approach. The main challenge is to match suitable classroom activities with the contents that have been uploaded on the learning portal (LMS). Those with limited teaching experience may find this as a hindrance to adopt flipped classroom. Thirdly, despite students' positive perceptions towards flipped classroom and their readiness to adopt 
technology for their learning, there is a mismatch between their perceptions and the mindsets. This may also happen to the educators, who appear to be resistance towards the use of technology, let alone flipped classroom. Apart from the lack of training on using flipped classroom and formulating appropriate activities and classroom materials, some educators may view flipped classroom as a substitute for their physical attendance in the classes. Although this research does not seek educators' views on this matter, it is inconclusive from the students' opinions on their learning processes, that some educators are still lacking in using technology for meaningful engagement.

To conclude, the Defence University must address training of educators to use technology appropriately. Uploading materials on the LMS is not the answer to teaching and learning with technology. Aligning the materials uploaded and the face-to-face sessions' activities is critical to ensure successful and meaningful learning engagement. Continuous training and constant monitoring are mandatory to assist educators in adopting flipped classroom.

\section{References}

Alsagof, Z., Baloch, H. \& Hashim, N. (2014). Flipping Large Lectures @ IMU. In M.A. Embi. (Ed.). Blended and Flipped Learning: Case Studies in Malaysia HEIs (pp. 255274). Bangi: Centre for Teaching and Learning Technologies, Universiti Kebangsaan Malaysia.

Bates, S. \& Galloway, R. (2012). The Inverted Classroom in a Large Enrolment Introductory Physics Course: A Case Study. A Report by the Higher Education Academy.

Camel, C. (2011). An Evaluation of the Flipped Classroom. Retrieved from https://camelportfolio.files.wordpress.com/2012/03/camel-c-final-epd-for-the-flippedclassroom.pdf on February 20, 2017.

Embi, M.A., Hussin, S. \& Panah, E. (2014). Flipped Learning Readiness Amongst Graduate and Postgraduate Students in UKM. In M.A. Embi. (Ed.). Blended and Flipped Learning: Case Studies in Malaysia HEIs (pp. 209-223). Bangi: Centre for Teaching and Learning Technologies, Universiti Kebangsaan Malaysia.

Lancaster, S. \& Read, D. (2013). Flipping Lectures and Inverting Classrooms. Education in Chemistry, September, 14-17.

Lee Kean Wah, Ng Shi Ing, Tan Choon Keong, Yoon Sook Jhee. (2014). To Flip or Not to Flip the Classroom? Findings from a Malaysian Undergraduate Course in UMS. In M.A. Embi. (Ed.). Blended and Flipped Learning: Case Studies in Malaysia HEIs (pp. 227-252). Bangi: Centre for Teaching and Learning Technologies, Universiti Kebangsaan Malaysia. 
McCarthy, J. (2016). Reflections on a Flipped Classroom in First Year Higher Education. Issues in Educational Research, 26(2), 332-350.

Papadapoulos, C. \& Roman, A.S. (2010). Implementing an Inverted Classroom Model in Engineering Statistics: Initial Results. American Society for Engineering Statistics. Proceedings of the 40th ASEE/IEEE Frontiers in Education Conference, Washington, D.C., October.

Perez, W. \& Dong, J. (2012). Flipping the Classroom: How to Embed Inquiry and Design Projects into a Digital Engineering Lecture. Paper presented at ASEE PSW Section Conference, California Polytechnic State University, San Luis Obispo.

Rivera, V.M. (2016). Flipped Classrooms: Advantages and Disadvantages from the Perspective of a Practising Art Teacher. MSc in Visual Arts Education. State University of New York (unpublished work).

Sam, S. \& Bergmann, J. (2012). Flip Your Classroom: Reach Every Student in Every Class Every Day. International Society for Technology in Education.

Schmidt, S.M.P. \& Ralph, D.L. (2014). The Flipped Classroom: A Twist on Teaching. The Clute Institute International Academic Conference, San Antonio, Texas, USA, 98-104.

Vanneman, M. \& Baker, K. (2017). Studies on the Effectiveness of Flipped Classrooms: Are We Comparing Apples to Apples? Medical Education, 51(12), 1. 